\title{
Efektifitas Pendidikan Kesehatan Terhadap Tekanan Darah Pada Lansia
}

\section{Cory Nelia Damayanti ${ }^{1}$, Mujib Hannan' ${ }^{2}$, Akhmad Feri Fatoni ${ }^{3}$}

${ }^{1,2,3}$ Prodi Keperawatan Universitas Wiraraja, Sumenep. Indonesia

1'corynelia@wiraraja.ac.id,²mujib@wiraraja.ac.id,'akhmadferi@wiraraja.ac.id

\section{INFORMASI ARTIKEL \\ Sejarah artikel: \\ Diterima: 08-11-2019}

Publikasi: 26-12-2019

Kata kunci:

Pendidikan Kesehatan,

Tekanan Darah,

Lansia

\section{ABSTRAK}

Peran tenaga kesehatan dalam melakukan pencegahan dinilai sangat penting mengingat tingginya angka hipertensi yang dialami oleh para lansia. Pendidikan kesehatan tentang hipertensi dapat meningkatkan kebiasaan, sikap dan pengetahuan, selain itu pendidikan kesehatan memiliki hubungan dengan kesehatan perseorangan, masyarakat, dan bangsa.

Desain penelitian pra eksperimen, dengan menggunakan desain group sebelum diberi perlakuan dan setelah diberi perlakuan. Populasi penelitian ini yaitu seluruh lansia penderita Hipertensi dengan Tekanan darah grade I di Posyandu Lansia Desa Pangarangan Kecamatan Kota Sumenep sebanyak 50 orang, Sampel penelitian ini yaitu sebagian lansia penderita Hipertensi sebanyak 44 orang. Teknik pengambilan Purpossive sampling melalui pendekatan kriteria inklusi dan ekslusi. Hasil dari analisa data dalam penelitian ini menggunakan Uji Paired samples t-tes.

Dari hasil penelitian ini didapatkan Tekanan Darah lansia sebelum diberikan pendidikan kesehatan sebagian besar tekanan darah pada stage II sebanyak 18 orang (20.5\%), Tekanan darah lansia sesudah diberikan pendidikan kesehatan sebagian besar pada stage I sebanyak 37 orang (42.1\%) dan Pendidikan kesehatan efektif terhadap tekanan darah pada lansia penderita darah tinggi di Posyandu Lansia Desa Pangarangan Kecamatan Kota Sumenep.

Semakin rendah pengetahuan seseorang, maka resiko terserang hipertensi akan semakin tinggi.
Key word:

health education, blood pressure, elderly

\begin{abstract}
The incidence of hypertension especially faced by elderly demands the role of health workers to prevent and promote about healthy. Health education about hypertension for personal can give benefit habits, attitudes and knowledge related to the health of individuals, communities, and nations. Pre-experimental research design and One-Group Pretest-Posttest Design was used in this research. Population of this research were elderly with hypertension grade I blood pressure in Integrated Healthcare Center located in Pangarangan Village, Sumenep as many as 50 people. The samples of this research were 44 elderly suffered by hypertension. Purpossive sampling technique using inclusion and exclusion criteria approach. Data analysis in this study used the Paired samples t-test.

The results of this study for elderly with blood pressure before given health education have basic pressure at stage II as many as 18 people (20.5\%). Elderly's blood pressure after given health education mostly at stage I as many as 37 people (42.1\%) and effective health education against pressure blood pressure in elderly with hypertension in Integrated Healthcare Center Elderly in Pangarangan Village, Sumenep.

Getting lower education level, getting high the risk of developing hypertension for elderly.
\end{abstract}

\section{PENDAHULUAN}

Salah satu penyebab meningkatnya jumlah penyakit menular dan tidak menular dalam satu komunitas masyarakat adalah faktor pengetahuan. Oleh sebab itu kita sebagai salah satu petugas kesehatan, sangatlah penting dan berkewajiban untuk memberikan pengetahuan dasar tentang penyakit tidak menular kepada 
masyarakat. Hasil penelitian kesehatan dasar dari badan penelitian dan pengembangan kesehatan tahun 2017 darah tinggi secara menunjukkan angka kejadian darah tinggi secara nasional 41,7\%. Darah tinggi ini penyebab kematian tertinggi ketiga setelah stroke dan TBC, yakni mencapai $7,7 \%$ dari populasi kematian pada semua umur di Indonesia (Depkes, 2017).

Seseorang dengan riwayat keturunan darah tinggi perlu untuk diberi nasehat mengenai perubahan life style. Orang dengan riwayat darah tinggi harus bisa menghindari kebiasaan merokok, diet yang kurang tepat, seperti kurang konsumsi makanan yang banyak mengandung serat, konsumsi gula, garam dan lemak berlebih. Hal ini diketahui berdasarkan penelitian bahwa responden lansia yang aktivitas fisik rendah memiliki peluang yang besar dan signifikan berhubungan terhadap kejadian darah tinggi (imam soeharto,2014). Menurut World Health Organizatiton usia lanjut adalah seseorang yang berusia 59 tahun atau lebih. Lansia merupakan usia yang beresiko tinggi terhadap penyakit, seperti penyakit jantung koroner, darah tinggi, kencing manis, Rematik dan kanker. Salah satu penyakit yang dialami oleh lansia adalah darah tinggi. (Ridwan, 2009).

Untuk mengurangi tingginya kejadian darah tinggi pada manula, adalah merupakan salah satu tugas dari tenaga kesehatan perawat ataupun dokter. Upaya yang bias dilakukan seperti melakukan pencegahan dan mempromosikan kesehatan tentang penyebab dan pencetus darah tinggi pada lansia. Beberapa cara yang bias dilakukan untuk mencegah agar terhindar dari penyakit darah tinggi adalah senam lansia, memberikan tatacara diet yang sehat, dan menghindari sesuatu hal yang dapat menyebabkan stress.

Berdasarkan hasil data dari Dinas Kesehatan di Kabupaten Sumenep tahun 2016 sebesar 44.403 jiwa sedangkan pada tahun 2017 mengalami peningkatan kejadian hipertensi sebesar 44.640 jiwa.Berdasarkan survei pendahuluan yang didapatkan Di Posyandu Desa Pangarangan tanggal 01 Agustus 2018 selama 1 bulan 2 kali dengan metode observasi terdapat sebanyak 22 lansia yang menderita penyakit hipertensi. Di Posyandu Desa Pangarangan pasien hipertensi yang memiliki tekanan darah 140-159 mmhg/90 - 99 mmhg sebanyak 9 orang (40\%), tekanan darah 160 - 179 mmhg / 100 109 mmhg sebanyak 8 orang(35\%) dan memiliki tekanan darah $\geq 180 \mathrm{mmhg} / \geq$ 110 mmhg sebanyak 5 orang(5\%).

Upaya pendidikan kesehatan yang perlu dilakukan untuk mengatasi darah tinggi pada lansia adalah dengan memberikan informasi kesehatan tentang pentingnya menjaga pola hidup sehat, istirahat cukup, manajemen stres yang positif dan olahraga. Rasa cemas akan timbul karena suatu permasalahan baru yang ada pada darah tinggi akan menimbulkan ketidakstabilan emosi atau salah satunya adalah rasa cemas. Perasaan itu timbul akibat rasa takut dan kurangnya informasi tentang apa yang di alaminya dan apa yang akan terjadi selanjutnya (Istirokah, 2013). Pendidikan kesehatan dapat memberikan tambahan informasi bagi lansia tentang pengelolaan kesehatan individu yaitu kesehatan mereka eka dan kesehatan orang lain (Notoadmojo, 2007). Pemberian informasi tentang kesehatan tidak hanya dipengaruhi oleh komunikasi informasi, tetapi juga dipengaruhi oleh persepsi diri seseorang, contohnya seperti kemauan untuk berubah menjadi lebih sehat dan kepercayaan diri untuk melakukan tindakan memperbaiki kesehatan. Informasi tentang pola hidup sehat merupakan bagian penting dari peran perawat yang profesional dalam upaya promosi kesehatan dan pencegahan penyakit (preventif) (Nursalam dan Effendy, 2008). Berdasarkan latar belakang diatas perlu dilakukan penelitian tentang efektifitas pendidikan kesehatan terhadap tekanan darah pada lansia.

\section{METODELOGI PENELITIAN}

Penelitian ini menggunakan exsperimental, dengan desain penelitian pretest sebelum diberikan perlakuan dan posttest setelah dilakukan perlakuan. Populasinya adalah seluruh lansia penderita Hipertensi dengan Tekanan darah grade I di Posyandu Lansia Desa Pangarangan Kecamatan Kota Sumenep sebanyak 50 orang, Sampel penelitian ini yaitu sebagian lansia penderita Hipertensi dengan Tekanan darah grade I di Posyandu Lansia Desa Pangarangan Kecamatan Kota Sumenep sebanyak 44 orang. Teknik pengambilan sampel pada penelitian ini yaitu Purpossive sampling melalui pendekatan kriteria inklusi dan ekslusi. Analisa data penelitian ini menggunakan Uji Paired samples t-tes. 
HASIL PENELITIAN

1. Karakteristik subjek penelitian

Berdasarkan Jenis Kelamin

Tabel 1 Frekuensi subjek penelitian Berdasarkan Jenis Kelamin

Hasil tabel 1 menunjukkan bahwa sebagian besar adalah wanita dengan jumlah 29 orang (65.9\%)

\begin{tabular}{cccc}
\hline \multirow{2}{*}{ No. } & Jenis & \multicolumn{2}{c}{ Subjek penelitian } \\
\cline { 3 - 4 } & Kelamin & $\mathrm{F}$ & Persentase \\
\hline 1 & Wanita & 15 & 34.1 \\
2 & Pria & 29 & 65.9 \\
\hline & Jumlah & 44 & 100 \\
\hline
\end{tabular}

2. Karakteristik subjek penelitian Berdasarkan Usia

Tabel 2 Frekuensi Berdasarkan Usia

\begin{tabular}{cccc}
\hline \multirow{2}{*}{ No. } & \multirow{2}{*}{ Usia } & \multicolumn{2}{c}{ Subjek penelitian } \\
\cline { 3 - 4 } & & F & Persentase \\
\hline 1 & $40-49$ & 11 & 25 \\
2 & $50-59$ & 20 & 45.5 \\
3 & $60-69$ & 13 & 29.5 \\
\hline \multicolumn{3}{l}{ jumlah } & \multicolumn{4}{c}{44} & 100 \\
\hline $\begin{array}{l}\text { Hasil tabel 2 } \\
\text { sebagian besar adalah 50-59 tahun dengan }\end{array}$ \\
jumlah 20 orang (45.5 \%)
\end{tabular}

3. Karakteristik subjek penelitian Berdasarkan Tingkat Pendidikan

Tabel 3 Responden subjek penelitian Tingkat Pendidikan

\begin{tabular}{cccc}
\hline \multirow{2}{*}{ No. } & \multirow{2}{*}{ Pendidikan } & \multicolumn{2}{c}{ Subjek penelitian } \\
\cline { 3 - 4 } & & F & Persentase \\
\hline 1 & SD & 33 & 75 \\
2 & SMP & 11 & 25 \\
\hline & jumlah & 44 & 100 \\
\hline
\end{tabular}

Hasil tabel 3 menunjukkan bahwa pendidikan terakhir sebagian besar adalah SD sebanyak 33 orang (75 \%)

\section{Karakteristik subjek penelitian Berdasarkan Pekerjaan}

Tabel 4 subjek penelitian Berdasarkan Pekerjan

\begin{tabular}{cccc}
\hline \multirow{2}{*}{ No. } & \multirow{2}{*}{ Pekerjaan } & \multicolumn{2}{c}{ Subjek penelitian } \\
\cline { 3 - 4 } & & F & Persentase \\
\hline 1 & Petani & 34 & 77.3 \\
\hline 2 & IRT & 10 & 22.7 \\
\hline & jumlah & 44 & 100 \\
\hline Hasil & tabel & 4 & menunjukkan bahwa
\end{tabular}
sebagian besar pekerjaan subjek penelitian adalah Petani 34 orang (77,3\%).

\section{Tekanan Darah Lansia Sebelum Pemberian Pendidikan Kesehatan}

Tabel 5 Frekuensi subjek penelitian dilihat dari hasil Tekanan Darah Lansia Sebelum Pemberian Pendidikan Kesehatan

\begin{tabular}{cccc}
\hline \multirow{2}{*}{ No. } & \multirow{2}{*}{ level } & \multicolumn{2}{c}{ Subjek penelitian } \\
\cline { 3 - 4 } & & $\mathrm{F}$ & Persentase \\
\hline 1 & Level I & 17 & 19.3 \\
2 & Level II & 18 & 20.5 \\
3 & Level III & 9 & 10.2 \\
\hline Total & & 44 & 100 \\
\hline
\end{tabular}

Berdasarkan tabel 5 menunjukkan secara deskriptif pada Tekanan Darah lansia sebelum diberikan pendidikan kesehatan sebagian besar tekanan daarah pada stage II sebanyak 18 orang (20.5\%).

\section{Tekanan Darah Lansia Sesudah Pemberian Pendidikan Kesehatan}

Tabel 6 Distribusi Frekuensi subjek penelitian Berdasarkan Tekanan Darah Lansia sesudah Pemberian Pendidikan Kesehatan

\begin{tabular}{cccc}
\hline \multirow{2}{*}{ No. } & \multirow{2}{*}{ level } & \multicolumn{2}{c}{ Subjek penelitian } \\
\cline { 3 - 4 } & & $F$ & Persentase \\
\hline 1 & level I & 37 & 42.1 \\
2 & level II & 6 & 6.8 \\
3 & level III & 1 & 1.1 \\
\hline & Total & 44 & 100 \\
\hline
\end{tabular}

Berdasarkan tabel 6 menunjukkan secara deskriptif pada Tekanan darah lansia sesudah diberikan pendidikan kesehatan sebagian besar pada stage I sebanyak 37 orang (42.1\%).

\section{Efektifitas Pendidikan Kesehatan Terhadap Tekanan Darah Pada Lansia}

Tabel 7 Efektifitas Pendidikan Kesehatan Terhadap Tekanan Darah Pada Lansia

\begin{tabular}{|c|c|c|c|c|c|c|}
\hline \multirow[b]{2}{*}{ No } & \multirow{2}{*}{ Stage } & \multicolumn{2}{|c|}{ Sebelum } & \multicolumn{2}{|c|}{ Sesudah } & \multirow[t]{2}{*}{ keterangan } \\
\hline & & Jumlah & Persentase & Jumlah & Persentase & \\
\hline 1 & level I & 17 & 19.3 & 37 & 42.1 & Meningkat \\
\hline 2 & level II & 18 & 20.5 & 6 & 6.8 & Menurun \\
\hline 3 & level III & 9 & 10.2 & 1 & 1.1 & Menurun \\
\hline & & 44 & 100 & 44 & 100 & \\
\hline
\end{tabular}


Uji Paired samples t-tes $=0.000$ (p value $<0.05$ )

Berdasarkan tabel 7 menunjukkan bahwa sebagian besar tekanan darah lansia sebelum di berikan pendidikan kesehatan pada kategori stage II sebesar 18 (20,5\%) lansia dan sesudah diberikan pendidikan kesehatan tekanan darah lansia pada stage I sebesar $37(42,1 \%)$ lansia. Berdasarkan hasil Uji statistik menggunakan Uji Paired samples $t$-tes $=0.000$ ( $p$ value $<0.05)$ yang menyatakan bahwa pendidikan kesehatan efektif terhadap tekanan darah pada lansia penderita darah tinggi di Posyandu Lansia Desa Pangarangan Kecamatan Kota Sumenep.

\section{PEMBAHASAN}

Hasil dari penelitian menunjukkan bahwa Tekanan Darah lansia sebelum diberikan pendidikan kesehatan sebagian besar tekanan dasarah pada stage II sebanyak 18 orang (20.5\%), dimana dengan karakteristik usia lansia sebagian besar pada rentang usia 50-59 tahun sebanyak 20 orang (45.5 \%). Sejalan dengan hasil penelitian Suprayitno (2019) penderita hipertensi stage II mencapai 34,38\%. hal tersebut menunjukkah bahwa dengan semakin meningkatnya usia seseorang , maka terjadi perubahan jaringan dan kinerja pada aorta. Yang secara otomatis akan menyebabkan kekakuan, ketidak optimalan kinerja pada dinding aorta. Penebalan pada dinding aorta disebabkan oleh bertambahnya jumlah struktur kolagen dan menghilangnya kadar ke elastisan di dalam lapisan medial arteri. Penebalan ini mengakibatkan penyempitan pada aliran darah aorta selama denyut sistol. Jika dinding aorta menjadi lebih sempit akibat penebalan, maka tekanan aliran darah dari jantung cenderung meningkat.

Menurut Jain (2011) pertambahan usia mengakibatkan semakin tua pembuluh darah utama yang cenderung tidak elastis dan lebih lemah, meningkatnya kelemahan mengakibatkan meningkatnya tekanan darah sistolik. Terhambatnya curah sirkulasi darah menyebabkan kinerja jantung semakin berat, yang berpengaruh ke kegagalan kerja jantung dengan bertambahnya intensitas pemompaan jantung yang memberikan gambaran peningkatan tekanan darah dalam sistem sirkulasi (Oktavia dkk. 2012).

Menurut Soeharto (2004) mengatakan apabila dilihat dari penyebabnya darah tinggi dibagi menjadi 2 yaitu faktor utama dan faktor pendukung. Yang menjadi pencetus dari darah tinggi primer adalah tekanan darah meningkat karena dipengaruhi oleh faktor usia. Pada usia 45 tahun, terjadi penebalan pada dinding arteri yang disebabkan karena adanya tumpukan zat kolagen pada lapisan otot, pada masa ini akan terjadi penyempitaan dan rasa kaku pada pembuluh darah .

Secara deskriptif tabel 5 menunjukkan pada Tekanan Darah lansia sebelum diberikan perlakuan pendidikan kesehatan sebagian besar tekanan daarah pada level II sebanyak 18 orang (20.5\%). Hasil Penelitian menunjukkan bahwa Tekanan darah lansia sesudah diberikan pendidikan kesehatan sebagian besar pada level I sebanyak 37 orang (42.1 \%). Pada karakteristik responden Tingkat pendidikan terakhir sebagian besar adalah SD sebanyak 33 orang (75 \%), dari hasil peneliian responden berpendidikan rendah tinggi resikonya mengalami hipertensi, hal tersebut bisa disebabkan kurangnya pengetahuan seseorang yang berpendidikan rendah sehingga agak sulit untuk memahami informasi yang disampaikan oleh tenaga kesehatan. Menurut Anggara dalam Prammana, (2016) mengatakan, tekanan darah dapat dipengaruhi oleh beberapa factor, salah satunya adalah factor pendidikan seseorang.

. Secara garis besar penyakit darah tinggi disebabkan karena kurangnya pengetahuan, kebiasaan yang tidak bermanfaat salah satunya yaitu merokok, mengkonsumsi minuman beralkohol, mengkonsumsi obat- obatan. Selain itu olahraga dan konsumsi makanan yang kurang benar juga menjadi salah satu faktor risiko untuk terjadinya penyakit darah tinggi. Salah satu contohnya asupan yang terlalu banyak mengandung garam dan berlemak.

Dari hasil penelitian, sebagian besar karakteristik responden berdasarkan jenis kelamin adalah wanita sebanyak 29 orang (65.9 \%), dimana wanita pada saat menjelang usia menopouse, produksi hormon seksual seperti estrogen menurun. Hormon estrogen mempunyai peranan penting dalam tubuh seorang wanita, seperti merangsang maturasi pada organ kewanitaan dan pemeliharaan struktur normal kulit dan pembuluh darah. Jika produksi hormon estrogen terus menurun dengan bertambahnya usia, maka fungsi untuk pemeliharaan struktur normal pembuluh darah juga akan menurun. 
Menurunnya fungsi pemeliharan hormon estrogen pada pembuluh darah, mengakibatkan pembuluh darah tidak elastis dan cenderung lebih kaku

Hasil penelitian menunjukkan sebagian besar tekanan darah lansia sebelum di berikan pendidikan kesehatan pada kategori level II sebesar 18 (20,5\%) lansia dan sesudah diberikan pendidikan kesehatan tekanan darah lansia pada stage I sebesar 37 (42,1\%) lansia. Berdasarkan hasil Uji statistik menggunakan Uji Paired samples t-tes $=0.000(\mathrm{p}$ value $<0.05)$ yang menyatakan bahwa pendidikan kesehatan efektif pada tekanan darah pada lansia penderita darah tinggi di Posyandu Lansia Desa Pangarangan Kecamatan Kota Sumenep. Pendidikan kesehatan tentang darah tinggi dapat mempengaruhi kebiasaan, sikap dan pengetahuan seseorang . oleh sebab itu factor tersebut erat hubungannya dengan kesehatan perorangan, dan kelompok.

Pendidikan kesehatan sangat penting mendukung program-program kesehatan lainnya. Kenyataanya pernyatan ini tidak sesuai dengan yang terjadi di sekitar kita. Yang terjadi pada saat ini program pelayanan kesehatan yang ada kurang melaksanakan pendidikan kesehatan. Yang sebenarnya pendidkian kesehatan sangat penting dan dibutuhkan oleh setiap orang, Karena pendidikan kesehatan dapat menghasilkan perubahan atau peningkatan pengetahuan masyarakat.

Informasi kebiasaan berprilaku hidup sehat bertujuan untuk meningkatkan ketrampilan ilmu masyarakat tentang kemadirian dan tanggung jawab kesehatan bagi dirinya sendiri, ataupun keluarganya. Dilihat dari segi promosi kesehatan, pendidikan kesehatan juga dapat memberikan pemahaman tentang budaya , dan kebiasaan masyarakat baik yang merugikan maupun yang menguntungkan kesehatan, sehingga dengan pendidikan kesehatan hipertensi yang di berikan pada lansia akan mengubah perilaku lansia dalam meningkatkan kesehatannya.

\section{KESIMPULAN}

1. Tekanan Darah lansia sebelum diberikan pendidikan kesehatan sebagian besar tekanan dasarah pada level II sebanyak 18 orang (20.5 \%) di Posyandu Lansia Desa Pangarangan Kecamatan Kota Sumenep

2. Tekanan darah lansia sesudah diberikan pendidikan kesehatan sebagian besar pada level I sebanyak 37 orang (42.1 \%) di Posyandu Lansia Desa Pangarangan Kecamatan Kota Sumenep

3. Pendidikan kesehatan efektif terhadap tekanan darah pada lansia penderita Hipertensi di Posyandu Lansia Desa Pangarangan Kecamatan Kota Sumenep

\section{SARAN}

1. Bagi Perawat

Hasil yang diharapkan hasil penelitian ini dapat bermanfaat dari segi pengetahuan bagi dunia keperawatan, khususnya dalam memberikan solusi terbaik untuk pasien darah tinggi.

2. Bagi masyarakat.

Hasil Penelitian diharapkan bisa memberikan kontribusi bahwa pentingnya ppengetahuan melalui pendidikan kesehatan untuk meningkatkan drajat kesehatan lansia khususnya dalam menurunkan tekanan darah pada lansia

3. Peneliti lainnya

penelitian ini semoga dapat diekmbangkan kembali oleh peneliti selanjutnya. Dan menjadi salah satu referensi dalam penelitian lainnya khusunya ,mengenai penelitian hipertensi

\section{DAFTAR PUSTAKA}

Ekowati R. 2009. Prevalensi Hipertensi dan Determinannya di Indonesia. Artikel Penelitian. Jakarta: Pusat penelitian Biomedis dan Farmasi Badan Penelitian Kesehatan Depertemen Kesehatan RI.

Ellisa, dkk (2009). Ilmu Penyakit Dalam Untuk Tenaga Medis. Jakarta: FKUI.

Fatmah.2010. Gizi Usia Lanjut. Erlangga : Jakarta.Gray, et al. (2005. Lecture Note Kardiologi edisi 4. Jakrta: Erlangga Medical Series.

Hidayat, S. (2014). Dzikir Khafi untuk Menurunkan Skala Nyeri Osteoartritis Pada Lansia. Jurnal Ilmu Kesehatan, 1(1), 13-22. https://doi.org/https://doi.org/10.24 929/jik.v1il.119

Hidayat, S. dan E. D. M. (2018). Terapi 
Kombinasi Sugesti Dan Dzikir Dalam Peningkatan Kualitas Tidur Pasien. Care: Jurnal Ilmiah Ilmu Kesehatan, 6(3), 219-230. Retrieved from https://jurnal.unitri.ac.id/index.php/ care/article/view/953

Hidayat, Syaifurrahman, Mujib Hannan, L. H. dan U. R. (2018). Klenengan Music Therapy on Sleep Quality in Elderly Patients at Pratama. Journal of Medical Science and Clinical Research, 6(12), 107-112. https://doi.org/https://dx.doi.org/10 $.18535 / \mathrm{jmscr} / \mathrm{v} 6 \mathrm{i} 12.16$

Hardi.(2009).100 Resep sembuhkan hipertensi, obesitas, dan asam urat. Jakarta:anggota IKAPI.

Hayens, B,dkk.(2003). Buku pintar menaklukkan Hipertensi.Jakarta: Ladang Pustaka.

Jain, Ritu. 2011. Pengobatan Alternative untuk mengatasi Tekanan darah. Gramedia Pustaka Utama. Jakarta.

Ridjab, D. (2005). Pengaruh Aktifitas Fisik Terhadap Tekanan Darah. Jurnal Kedokteran Atmajaya 4(2):73

Ridwan. 2009. Hipertensi dan Faktor Resikonya dalam Kajian Epidemiologi. Jakarta.

Sasmita, A. (2009). Pengaruh Senam Senam lansia Selama 12 Minggu Terhadap Tekanan Darah Diastol dan Sistol Hi pertensi. Media Keperawatan 1(1)

Soeharto, Iman. 2004. Serangan Jantung dan Stroke Hubungannya dengan Lemak dan Kolestrol, edisi kedua, Penerbit PT. Gramedia Pustaka Utama. Jakarta.

Sheps, (2005). Mengatasi Tekanan Darah Tinggi. Jakarta: Intisari Mediatama

Smeltzer, B. (2002). Keperawatan Medikal Bedah Eidisi 8 Vol 2. Jakarta: EGC.

Suprayitno, E., Damayanti, C. N., \& Hannan, M. (2019). Gambaran Status Tekanan Darah Penderita Hipertensi di Desa Karanganyar Kecamatan Kalianget Kabupaten Sumenep. Journal Of Health Science (Jurnal Ilmu Kesehatan), 4(2), 20-24.

Triyanto, E., Iskandar, A., \& Saryono. (2012) Pengaruh Aplikasi Health Promotion Model Terhadap Peningkatan Kualitas Kelompok Peduli Hipertensi. Soedirman Nursing Jurnal 7(2)125:134Sindhu,
P.2010. Panduan lengkap senam lansia., Jakarta: Kaifa. 